\title{
Pengelolaan dan Pemupukan Fosfor dan Kalium pada Pertanian Intensif Bawang Merah di Empat Desa di Brebes
}

\author{
Management and Fertilization of Phosphorus and Potassium \\ on Shallot Intensive Cultivation in Four Villages in Brebes
}

\author{
Muliana $^{1}$, Syaiful Anwar ${ }^{2}$, Arief Hartono ${ }^{2}$, Anas D. Susila ${ }^{3}$, dan Supiandi Sabiham ${ }^{2}$
}

Diterima 17 Januari 2018/Disetujui 07 Maret 2018

\begin{abstract}
The management and fertilization of shallot cultivation in Brebes is very intensive. The purpose of this research was to study crop management and phosphorus $(P)$ and potassium $(K)$ fertilizations of shallot cultivation by smallholder farmers in four villages in Brebes. The data were collected through survey method, interview, and questionnaires to 14 respondent farmers, and analysis of $P$ and $K$ content of farmer's soil samples from two villages. The results showed that the cropping index (IP) was 400-500\% comprised of three to four times of shallot cultivation and one rice cultivation. The fertilizations of $\mathrm{P}$ and $\mathrm{K}$ were 22-171 $\mathrm{kg}$ of $\mathrm{P}_{2} \mathrm{O}_{5} \mathrm{ha}^{-1}$ and 22-213 $\mathrm{kg} \mathrm{K}_{2} \mathrm{O} \mathrm{ha} \mathrm{h}^{-1}$, respectively, while the recommended rates were $54 \mathrm{~kg}_{2} \mathrm{O}_{5} \mathrm{ha}^{-1}$ and $78 \mathrm{~kg} \mathrm{~K}_{2} \mathrm{O} \mathrm{ha}{ }^{-1}$, respectively. This varied fertilizations were not significantly correlated with productions, except fertilization of $K$ with production in rainy season that was significantly correlated at $P<0.05(n=14, r=0.532)$. The soil $P$ status was very high at all locations and at all depths $(0-0.8 \mathrm{~m})$, while the soil $K$ status ranged from medium to very high.
\end{abstract}

Keywords: nutrient accumulation, nutrient availability, nutrient residue, nutrient status, smallholder farmers

\begin{abstract}
ABSTRAK
Pengelolaan dan pemupukan pada budidaya bawang merah di Brebes sangat intensif. Tujuan penelitian ini ialah mengkaji pengelolaan pertanaman dan pemupukan fosfor $(\mathrm{P})$ dan kalium $(\mathrm{K})$ bawang merah yang dilakukan petani di empat desa di Brebes. Pengumpulan data dilaksanakan melalui metode survei, wawancara, dan pengisian kuisioner kepada 14 petani responden, dan analisis kadar P dan K sampel tanah lahan petani responden dari dua desa. Hasil penelitian menunjukkan bahwa indeks pertanaman (IP) adalah 400-500\% dengan pertanaman bawang merah tiga sampai empat kali dan satu kali pertanaman padi. Pemupukan P dan K berturut-turut berkisar 22-171 kg $\mathrm{P}_{2} \mathrm{O}_{5}$ ha $^{-1}$ dan 22-213 kg K $2 \mathrm{O} \mathrm{ha}^{-1}$, sementara rekomendasi Distan Brebes berturut-turut adalah $54 \mathrm{~kg}$ $\mathrm{P}_{2} \mathrm{O}_{5} \mathrm{ha}^{-1}$ dan $78 \mathrm{~kg} \mathrm{~K}_{2} \mathrm{O}$ ha $^{-1}$. Pemupukan bervariasi ini tidak berkorelasi nyata dengan produksi, kecuali pemupukan $\mathrm{K}$ dengan produksi pada musim hujan yang berkorelasi nyata pada taraf $5 \%$ $(\mathrm{n}=14, \mathrm{r}=0.532)$. Status $\mathrm{P}$ tanah sangat tinggi pada semua lokasi dan pada semua kedalaman $(0-0.8$ $\mathrm{m})$, sementara status $\mathrm{K}$ tanah lebih bervariasi, yaitu dari sedang sampai sangat tinggi.
\end{abstract}

Kata kunci: akumulasi hara, ketersediaan hara, petani kecil, residu hara, status hara

\footnotetext{
${ }^{1}$ Program Studi Agroekoteknologi, Fakultas Pertanian, Universitas Malikussaleh, Aceh Utara, Aceh 24355, Indonesia ${ }^{2}$ Departemen Ilmu Tanah dan Sumberdaya Lahan, Fakultas Pertanian, Institut Pertanian Bogor

J1. Meranti, Kampus IPB Darmaga, Bogor 16680, Indonesia

${ }^{3}$ Departemen Agronomi dan Hortikultura, Fakultas Pertanian, Institut Pertanian Bogor

Jl. Meranti, Kampus IPB Darmaga, Bogor 16680, Indonesia

Email: syaianwar@yahoo.com (*Penulis korespondensi)
} 


\section{PENDAHULUAN}

Intensifikasi merupakan penggunaan lebih banyak faktor produksi, tenaga kerja dan modal atas sebidang tanah tertentu untuk mencapai hasil produksi yang lebih besar (Mubyarto, 1991). Pertanian intensif memicu penggunaan pupuk anorganik yang berlebihan, telah menjadikan terakumulasinya hara di dalam tanah. Sebagian besar tanah pertanian di Indonesia telah terjadi akumulasi hara $\mathrm{P}$ (fosfor) dan $\mathrm{K}$ (kalium) dengan status tinggi (Balitbangtan, 2006; Hartono et al., 2015). Berdasarkan peta status hara $\mathrm{P}$ dan $\mathrm{K}$ tanah sawah, bahwa dari sekitar 7.5 juta ha lahan sawah di Indonesia, $40 \%$ berstatus $\mathrm{P}$ tinggi, $43 \%$ berstatus $\mathrm{P}$ sedang dan $17 \%$ status $\mathrm{P}$ rendah. Status K tinggi sekitar $50 \%$, status K sedang 37\%, dan status $\mathrm{K}$ rendah $12 \%$ (Balitbangtan, 2006). Hasil analisis menggunakan $\mathrm{HCl} 25 \%$ menunjukkan bahwa dari seluas 52421 ha tanah sawah di Brebes yang juga digunakan untuk pertanaman bawang merah, $99.95 \%$ telah mengalami akumulasi residu $\mathrm{P}$ tinggi dan $99.59 \% \mathrm{~K}$ tinggi (Balitbangtan, 2006).

Bawang merah merupakan salah satu komoditas pertanian strategis di Indonesia. Kabupaten Brebes merupakan salah satu wilayah yang dikenal sebagai sentra produksi bawang merah. Pertanian bawang merah di Brebes dilakukan secara intensif, yaitu adanya praktek pengolahan tanah dengan membuat parit dan bedengan, dan aplikasi pupuk anorganik yang rutin dengan dosis dan intensitas tinggi.

Penggunaan pupuk $P$ dan $K$ yang intensif telah berakibat kepada terakumulasinya pada tanah pertanian Brebes. Namun demikian, petani masih terbiasa untuk terus melakukan pemupukan. Sejauh mana adanya akumulasi residu $\mathrm{P}$ dan $\mathrm{K}$ pada tanah pertanian bawang merah intensif di Brebes perlu dipelajari secara mendalam. Berkaitan dengan uraian di atas, maka penelitian melalui survei dan analisis kadar P dan K pada tanah pertanian intensif di Brebes penting dilaksanakan. Lebih jauh lagi, penelitian ini penting dalam upaya pembinaan pertanian, khususnya pengelolaan hara yang lebih efisien dan ramah lingkungan. Penelitian ini dilakukan untuk mendapatkan informasi, perlakuan pemupukan apa saja dan dengan dosis berapa yang diberikan petani pada praktek pertaniannya, serta bagaimana karakteristik $\mathrm{P}$ dan $\mathrm{K}$ lebih detil pada tanah pertanian tersebut.
Penelitian ini bertujuan: mendapatkan informasi tentang pengelolaan tanaman dan pemupukan oleh petani di empat desa, dan (2) menganalisis tingkat residu P dan $\mathrm{K}$ di dalam tanah pertanian intensif bawang merah di dua desa di Brebes.

\section{BAHAN DAN METODE}

Penetapan lokasi dan responden penelitian secara sengaja (purposive) dengan pertimbangan bahwa daerah tersebut merupakan daerah pertanian intensif sebagai sentra produksi bawang merah dan petani yang telah berpengalaman minimal 10 tahun. Penetapan lokasi didasarkan juga pada informasi status hara $\mathrm{P}$ dan $\mathrm{K}$ tanah tinggi (Balitbangtan, 2006; Hartono et al., 2015). Lokasi penelitian ditetapkan pada empat desa pada tiga kecamatan, yaitu Desa Siasem, Desa Sisalam, Desa Kersana dan Desa Pemaron, dengan total responden sebanyak 14 petani. Penelitian dilaksanakan mulai bulan Mei 2015 sampai Desember 2016.

\section{Pengelolaan Tanaman dan Pemupukan}

Pengumpulan data mengenai bagaimana pengelolaan tanaman dan pemupukan pada pertanian intensif di empat desa di Brebes menggunakan metode survei, wawancara dan pengisian kuesioner dengan 14 petani sebagai responden. Penetapan responden dilakukan berdasar prinsip purposive dan snowball sampling. Jumlah responden tidak dibagi merata setiap desa sampling karena diambil langsung ketika survei ke area pertanaman bawang merah, namun dipastikan bahwa responden telah 10 tahun atau lebih bertani bawang merah. Survei, wawancara dan pengisian kuesioner dimaksudkan untuk menggali informasi mengenai pengelolaan tanaman dan pemupukan yang dilakukan petani dalam budidaya tanaman khususnya bawang merah di Brebes. Informasi lain yang digali ialah karakteristik petani, luas dan status lahan usaha, pola pertanaman, serta produksi. Analisis data dilakukan secara deskriptif kualitatif dan kuantitatif. Data hasil survei, wawancara yang dibantu dengan kuisioner, kemudian diklasifikasikan dan dihitung menggunakan statistik sederhana, seperti menjumlahkan, membagi, mengali, persentase 
dan korelasi, kemudian disintesis dan disajikan dalam bentuk tabel atau gambar.

\section{Pengambilan Sampel dan Analisis Kandungan P dan K Tanah}

Sampel tanah diambil secara vertikal pada 4 lapisan pada kedalaman 0-20, 20-40, 40-60 dan $60-80 \mathrm{~cm}$ pada 2 profil masingmasing di Desa Siasem dan di Desa Kersana. Tanah dikering-udarakan, kemudian dihaluskan sehingga lolos saringan $2 \mathrm{~mm}$. Tanah kemudian dianalisis untuk penetapan $\mathrm{pH} \quad \mathrm{H}_{2} \mathrm{O}$ (elektroda gelas), kandungan $\mathrm{P}$ tersedia dengan metode Olsen (pengekstrak $0.5 \mathrm{M} \mathrm{NaHCO}_{3} \mathrm{pH} 8.5$ ), dan kandungan $\mathrm{P}$ dan $\mathrm{K}$ potensial dengan pengekstrak $\mathrm{HCl} 25 \%$. Kedua unsur ini menjadi perhatian dikarenakan statusnya yang telah terakumulasi di tanah. Prosedur analisis mengikuti petunjuk teknis analisis sifat kimia tanah (Eviati dan Sulaeman, 2012). Penetapan P menggunakan UV-Vis Spectrophotometer, sedangkan penetapan K menggunakan Flamephotometer.

\section{HASIL DAN PEMBAHASAN}

\section{Karakteristik Petani}

Karakteristik petani responden dalam penelitian ini mencakup umur, pendidikan formal, jumlah anggota keluarga dan pengalaman bertani bawang merah. Usia petani responden dalam penelitian ini berkisar 30-55 tahun dengan usia rata-rata 46 tahun. Pendidikan sekolah lanjutan tingkat atas (SLTA) dan sekolah lanjutan tingkat pertama (SLTP) masing-masing 14\%, sekolah dasar 43\% dan tanpa sekolah 29\%. Jumlah anggota keluarga rata-rata 5 orang. Pengalaman bertani bawang merah berkisar 10-40 tahun dengan rata-rata 22 tahun. Data tersebut menunjukkan bahwa pengelolaan pertanian praktis dilaksanakan oleh petani usia produktif dengan tingkat pendidikan formal rata-rata relatif rendah, namun pengalaman bertani bawang merah sudah memadai $(\geq 10$ tahun). Karakteristik petani responden pada penelitian ini disajikan pada Tabel 1.

\section{Luas dan Status Lahan Garapan}

Berdasarkan hasil survei dan informasi dari responden yang diwawancarai, luas lahan yang digarap oleh setiap petani berbeda-beda, mulai dari $1000 \mathrm{~m}^{2}$ sampai dengan dua hektar. Tetapi pada umumnya, luas lahan garapan sekitar 0.32 ha atau sekitar 0.28 bahu (bau). Bahu (bau) adalah istilah yang digunakan untuk menyatakan ukuran tanah di Brebes. Selain satuan bahu, terdapat juga satuan amas dan bata. Berdasarkan berbagai informasi, ukuran luas tanah satu bahu, satu amas, dan satu bata berturut-turut ditetapkan seluas 7000 , 1000 , dan $14.06 \mathrm{~m}^{2}$.

Tabel 1. Karakteristik petani (responden) bawang merah di empat desa di Brebes

\begin{tabular}{lcccccc}
\hline Kecamatan & Desa & Responden & $\begin{array}{c}\text { Umur } \\
\text { (Tahun) }\end{array}$ & Pendidikan & $\begin{array}{c}\text { Jumlah } \\
\text { Anggota } \\
\text { Keluarga }\end{array}$ & $\begin{array}{c}\text { Pengalaman Bertani } \\
\text { Bawang Merah } \\
\text { (Tahun) }\end{array}$ \\
\hline Kersana & Kersana & 1 & 55 & SD & 4 & 20 \\
Wanasari & Siasem & 2 & 30 & SD & 5 & 20 \\
& & 4 & 52 & - & 5 & 10 \\
& & 5 & 49 & SLTP & 7 & 30 \\
Brebes & Sisalam & 6 & 55 & - & 4 & 10 \\
& Pemaron & 7 & 45 & SLTA & 5 & 25 \\
& & 8 & 43 & - & 5 & 25 \\
& & 9 & 43 & - & - & 20 \\
& & 10 & 49 & SLTA & 5 & 40 \\
& 11 & 52 & SD & 5 & 20 \\
& & 12 & 49 & SD & 4 & 15 \\
& & 13 & 33 & SLTP & 4 & 14 \\
\hline
\end{tabular}


Tabel 2. Luas lahan, lebar bedengan, lebar dan kedalaman parit pada pertanaman bawang merah di empat desa di Brebes

\begin{tabular}{|c|c|c|c|c|c|c|}
\hline \multirow{2}{*}{ Responden } & \multicolumn{2}{|c|}{ Luas dan Status Lahan Garapan } & \multirow{2}{*}{$\begin{array}{l}\text { Status } \\
\text { Lahan }\end{array}$} & \multirow{2}{*}{$\begin{array}{c}\text { Lebar } \\
\text { Bedeng (m) }\end{array}$} & \multirow{2}{*}{$\begin{array}{c}\text { Lebar } \\
\text { Parit (m) }\end{array}$} & \multirow{2}{*}{$\begin{array}{l}\text { Kedalaman } \\
\text { Parit }(\mathrm{m})^{*}\end{array}$} \\
\hline & Satuan Setempat & $\mathrm{m}^{2}$ & & & & \\
\hline 1 & 1/4bahu & 1750 & $\mathrm{~S}$ & 1.5 & 0.6 & 0.4 \\
\hline 2 & 1/4bahu & 1750 & $\mathrm{~S}$ & 2.0 & 0.5 & 0.8 \\
\hline 3 & $1 / 8$ bahu & 875 & $\mathrm{~S}$ & 1.2 & 0.5 & 0.5 \\
\hline 4 & 1/4bahu & 1750 & BH & 1.5 & 0.4 & 0.4 \\
\hline 5 & $1 / 2$ bahu & 3500 & $\mathrm{~S}$ & 1.5 & 0.6 & 0.4 \\
\hline 6 & 2 hektar & 20000 & MS\&S & 1.5 & 0.4 & 0.5 \\
\hline 7 & $1 / 2$ bahu & 3500 & $\mathrm{~S}$ & 1.5 & 0.4 & 0.4 \\
\hline 8 & 1/4bahu & 1750 & $\mathrm{~S}$ & 1.5 & 0.5 & 0.5 \\
\hline 9 & 1/4bahu & 1750 & $\mathrm{~S}$ & 1.5 & 0.4 & 0.4 \\
\hline 10 & 1/4hektar & 2500 & $\mathrm{~S}$ & 1.5 & 0.4 & 0.4 \\
\hline 11 & 1/2bahu & 3500 & $\mathrm{~S}$ & 1.5 & 0.4 & 0.4 \\
\hline 12 & 1 amas & 1000 & $\mathrm{~S}$ & 1.5 & 0.5 & 0.4 \\
\hline 13 & $1 / 4$ hektar & 2500 & $\mathrm{~S}$ & 1.5 & 0.4 & 0.6 \\
\hline 14 & 100 bata & 1406 & S & 0.6 & 0.5 & 0.5 \\
\hline
\end{tabular}

Keterangan: $\mathrm{S}=$ sewa; $\mathrm{BH}=$ bagi hasil; $\mathrm{MS}=$ milik sendiri; $*=$ kedalaman parit awal.

Status lahan garapan pada umumnya penyewaan tahunan $(86 \%)$. Hanya sebagian kecil dengan sistem bagi hasil (7\%), dan milik sendiri (7\%). Luas lahan garapan, status lahan, lebar bedengan, lebar dan kedalaman parit masing-masing petani responden disajikan pada Tabel 2.

Lebar dan kedalaman bedengan pada awal pembuatan rata-rata sekitar $0.4 \mathrm{~m}$. Seiring dengan perawatan pertanaman dan masa pertanaman berikutnya, tanah di dalam parit selalu diambil untuk diletakkan ke atas dan untuk memadatkan samping bedengan, yang disebut (istilah setempat) malem. Dikarenakan pelaksanaan malem ini secara terus menerus, mengakibatkan kedalaman parit semakin bertambah seiring kegiatan pertanaman bawang berikutnya, hingga dapat mencapai $0.8 \mathrm{~m}$.

\section{Pengelolaan Tanaman}

Penanaman bawang merah dilakukan tiga sampai empat kali umumnya berturutturut dan penanaman padi satu kali, dengan IP (indeks pertanaman) 400-500\% dalam setahun. Jika keadaan iklim dan keuangan tidak mendukung, sebagian besar petani menggantikan tanaman bawang merah dengan tanaman lain yang membutuhkan biaya relatif lebih rendah (seperti tanaman cabai, kedelai, jagung, atau terong), atau tanah dibera (tidak ditanami). Penggantian tanaman atau bera tersebut menurut petani juga memiliki tujuan perlakuan konservasi tanah. Penanaman padi hampir selalu dilakukan sekali setahun pada umumnya dilakukan pada musim hujan, yang mana umumnya pertanaman bawang merah lebih riskan. Pada saat pertanaman padi, bedeng/parit lahan diratakan untuk kemudian dibuat bedeng/parit kembali saat akan dilakukan penanaman bawang merah di musim berikutnya. Pola dan indeks pertanaman masing-masing responden dalam satu tahun disajikan pada Tabel 3 .

\section{Penanaman Bawang Merah}

Penanaman bawang merah seluas 1750 $\mathrm{m}^{2}$ menghabiskan benih lebih kurang $300 \mathrm{~kg}$ atau 1.4 ton $\mathrm{ha}^{-1}$. Benih bawang merah yang digunakan biasanya varietas Bima Brebes. Benih bawang merah khusus dipersiapkan pada saat panen bawang merah sebelumnya, atau didapatkan dari penangkar benih setempat yang sudah berpengalaman dalam penangkaran benih bawang merah. Apabila benih yang digunakan belum mencapai dua bulan umur simpan, maka benih terlebih dahulu dipotong $1 / 3$ bagian ujung untuk menstimulasi percepatan tumbuh. Penanaman dilakukan dengan jarak tanam sekitar $15 \mathrm{~cm}$ x $10 \mathrm{~cm}$.

\section{Pemupukan}

Petani responden melakukan pemupukan bawang merah dengan pupuk anorganik tanpa menggunakan pupuk organik. Sebagian besar petani melakukan pemupukan tiga sampai empat tahap, namun ada juga yang melakukannya 
mencapai lima tahap. Pemupukan tahap pertama dikerjakan sekitar satu minggu sebelum penanaman bawang merah, tahap kedua dilakukan pada umur tanaman bawang merah 5-7 hari, tahap ketiga umur 15-25 hari, tahap keempat umur 20-45 hari dan tahap kelima umur 35-45 hari setelah tanam. Responden menggunakan pupuk anorganik dengan jenis dan dosis beragam dan tidak berpatokan pada rekomendasi Dinas Pertanian (Distan) Brebes. Pupuk anorganik yang digunakan petani adalah pupuk tunggal dan pupuk majemuk yang kandungan hara utamanya adalah nitrogen $(\mathrm{N})$, kalium $(\mathrm{K})$ dan fosfor $(\mathrm{P})$. Jenis pupuk yang digunakan petani mencakup Urea, ZA, NPK Phonska, NPK (impor), SP-36, DAP, KCl, Kamas dan Grower. Pupuk anorganik yang direkomendasikan oleh Distan Brebes adalah: Urea $250 \mathrm{~kg} \mathrm{ha}^{-1}$; ZA $180 \mathrm{~kg} \mathrm{ha}^{-1}$; SP-36 $150 \mathrm{~kg} \mathrm{ha}^{-1}$; KCl $150 \mathrm{~kg} \mathrm{ha}^{-1}$ (Distan Brebes, 2007).

Penggunaan jenis dan dosis pupuk yang berbeda antar petani dan rekomendasi Distan Brebes mengakibatkan selisih jumlah unsur hara yang bervariasi ketika dibandingkan. Gambar 1 dan 2 menyajikan jumlah pupuk $\mathrm{P}$ dan $\mathrm{K}$ dari berbagai pupuk yang diberikan petani, dibandingkan dengan jumlah pupuk $\mathrm{P}$ dan $\mathrm{K}$ yang direkomendasikan Distan Brebes. Terdapat $66 \%$ petani menggunakan pupuk $\mathrm{P}$ melebihi dosis rekomendasi dan $44 \%$ di bawah rekomendasi Distan Brebes (Gambar 1). Jumlah pupuk $\mathrm{P}$ yang diberikan petani responden berkisar 22-171 dengan rata-rata 81, sementara rekomendasi Distan Brebes adalah $54 \mathrm{~kg} \mathrm{P}_{2} \mathrm{O}_{5} \mathrm{ha}^{-1}$. Pada pemupukan $\mathrm{K}, 43 \%$ petani di atas dosis rekomendasi dan $57 \%$ di bawah dosis rekomendasi (Gambar 2). Jumlah pupuk K yang diberikan petani berkisar 22213 dengan rata-rata 88 , sementara rekomendasi Distan Brebes adalah $78 \mathrm{~kg} \mathrm{~K}_{2} \mathrm{O} \mathrm{ha}^{-1}$.

Pemupukan berlebih yang berlangsung lama dapat secara langsung meningkatkan residu unsur pupuk dalam tanah, terutama $\mathrm{P}$ yang cenderung diimobilisasi oleh tanah (Yan et al., 2017). Pemupukan berlebihan juga dapat terbawa keluar areal pertanian yang mengakibatkan pencemaran badan-badan air serta memicu proses eutrofikasi (Rowe et al., 2016; Rodrigues et al., 2016; Chen et al., 2017).

Penggunaan pupuk $\mathrm{P}$ dan $\mathrm{K}$ dengan rentang dosis yang sangat bervariasi, lebih tinggi atau lebih rendah dari rekomendasi Distan Brebes menjadi indikasi sudah kurang berjalannya pembinaan petani, khususnya terkait dosis pemupukan. Alasan utama petani memupuk dalam jumlah banyak (di atas rekomendasi) dengan beraneka pupuk adalah untuk lebih memastikan berhasilnya panen. Selain itu, banyak tawaran kepada petani untuk menggunakan berbagai pupuk atau amelioran. Alasan petani tidak terlalu memupuk (di bawah rekomendasi) terutama dikarenakan tidak adanya modal. Hasil wawancara mendalam kepada petani yang memupuk di bawah rekomendasi, terdapat indikasi bahwa pemupukan tetap diperlukan tetapi jumlahnya tidak perlu banyak.

Tabel 3. Pola dan indeks pertanaman di lahan sawah di empat desa di Brebes

\begin{tabular}{ccccccc}
\hline \multirow{2}{*}{ Responden } & \multicolumn{7}{c}{ Pola Tanam } & \multirow{2}{*}{ IP $(\%)$} \\
\cline { 2 - 5 } & $4-5$ & $6-7$ & $8-9$ & $10-11$ & $12-1-2$ & \\
\hline 1 & bawang & bawang & bawang & bawang & padi & 500 \\
2 & bawang & bawang & bawang & - & padi & 400 \\
3 & bawang & - & lain-lain & bawang & padi & 400 \\
4 & bawang & bawang & - & - & padi & 400 \\
5 & bawang & bawang & bawang & - & padi & 400 \\
6 & TL & bawang & - & bawang & padi & 400 \\
7 & - & bawang & bawang & bawang & padi & 400 \\
8 & bawang & bawang & lain-lain & - & padi & 400 \\
9 & bawang & bawang & bawang & - & padi & 400 \\
10 & bawang & bawang/TL & bawang & - & padi & 400 \\
11 & bawang & bawang/TL & bawang & - & padi & 400 \\
12 & bawang & bawang/TL & bawang/TL & - & padi & 400 \\
13 & bawang & bawang/TL & bawang/TL & - & padi & 400 \\
14 & bawang & bawang & bawang & bawang & padi & 500 \\
\hline
\end{tabular}

Keterangan: TL = tanaman lain (cabai, kedelai, jagung); - = bera; 4-5 = April-Mei; 6-7 = Juni-Juli; 8-9 = AgustusSeptember; $10-11=$ Oktober-November; $12-1-2=$ Desember - Januari-Februari. 


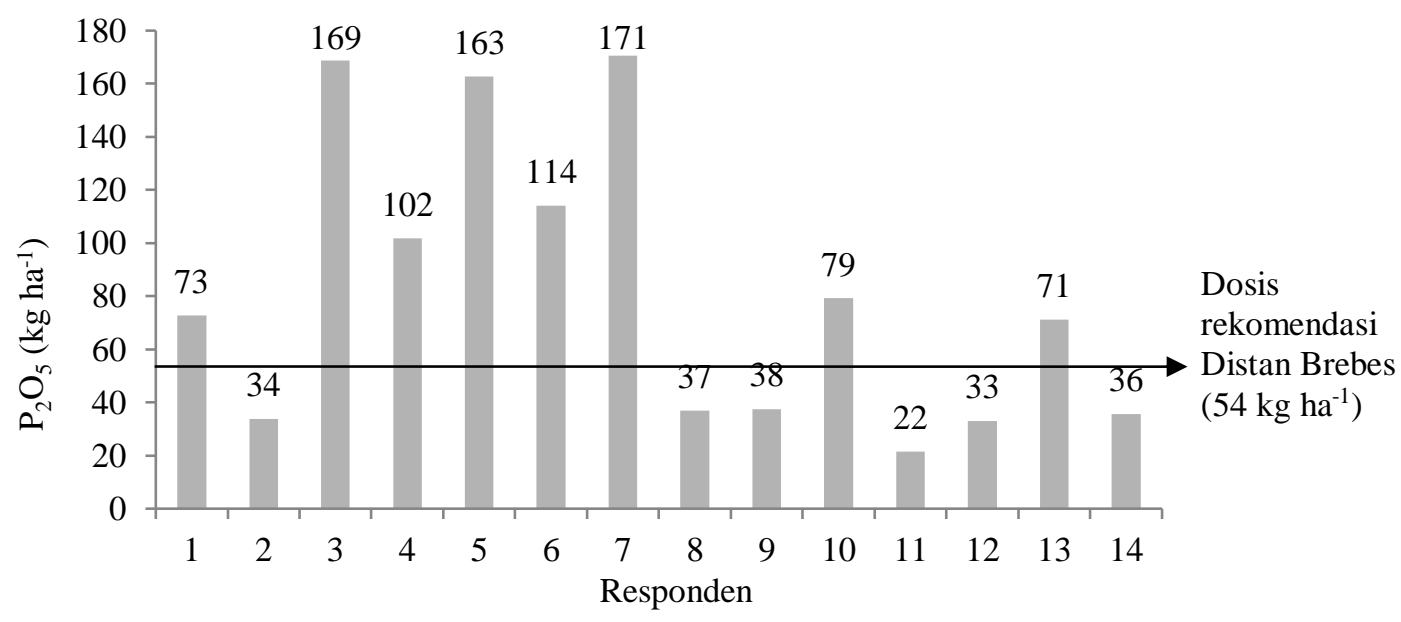

Gambar 1. Jumlah $\mathrm{P}_{2} \mathrm{O}_{5}$ dalam dosis pupuk yang digunakan petani pada setiap pertanaman bawang merah.

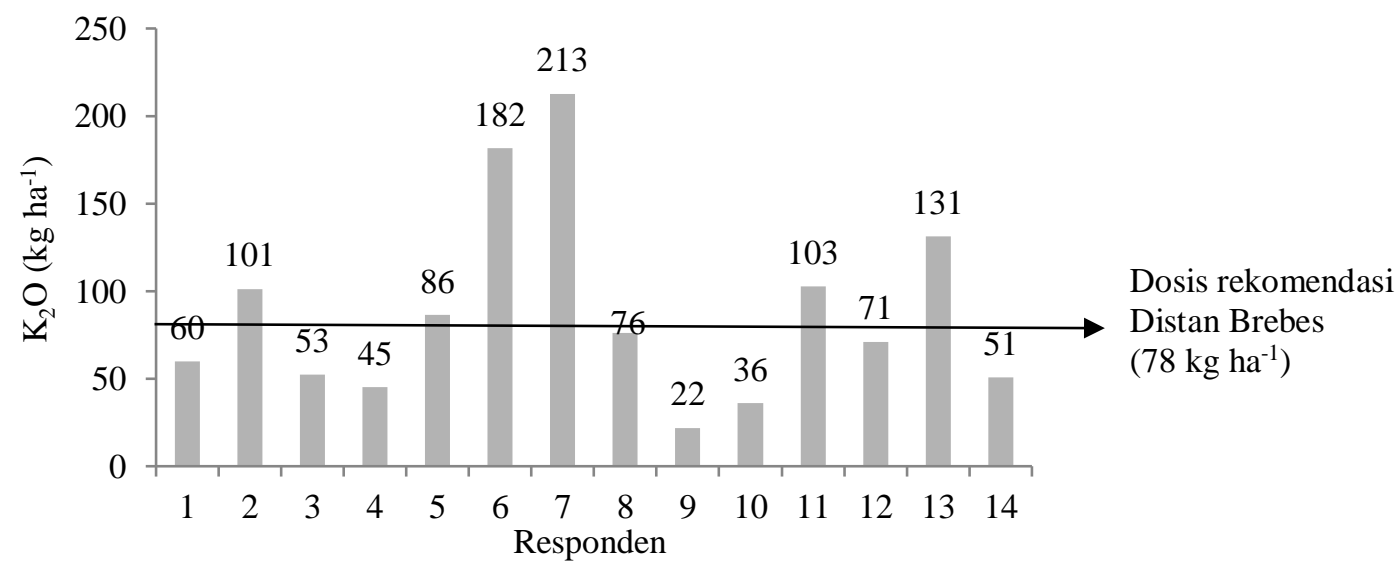

Gambar 2. Jumlah $\mathrm{K}_{2} \mathrm{O}$ dalam dosis pupuk yang digunakan petani pada setiap pertanaman bawang merah.

\section{Pemanenan dan Produksi}

Pada musim kemarau, bawang merah dipanen pada umur 60-65, sedangkan pada musim hujan 50-55 hari setelah tanam. Setelah panen, bawang merah dijemur dua hari sebelum dijual. Khusus untuk bibit penjemurannya dilakukan selama sekitar enam hari tergantung pada cuaca. Produktivitas bawang merah petani responden disajikan pada Tabel 4. Produktivitas bawang merah lebih tinggi pada musim kemarau, yaitu pertanaman Bulan Juni-Juli dan SeptemberOktober, yang mencapai rata-rata 11.03 ton ha ${ }^{-1}$. Pada musim hujan produktivitas hanya 6.10 ton $\mathrm{ha}^{-1}$. Rendahnya produktivitas bawang merah pada musim hujan berhubungan erat dengan cuaca, khususnya tingginya curah hujan dan berkurangnya penyinaran matahari. Curah hujan yang tinggi dan kurangnya penyinaran meningkatkan serangan hama dan penyakit tanaman bawang merah. Menghadapi situasi demikian, petani melakukan antisipasi dengan meningkatkan penggunaan pestisida dan pupuk kalium serta mengurangi pupuk nitrogen. Selain itu, curah hujan yang tinggi dengan intensitas dan lama penyinaran matahari yang kurang, membuat tanaman tidak dapat melakukan fotosintesis dan metabolisme secara optimal.

Produktivitas bawang merah yang dicapai petani di empat desa di Brebes ratarata pada musim kemarau berada di antara rata-rata produktivitas bawang merah Provinsi Jawa Tengah dan produktivitas nasional pada tahun 2015, yaitu berturut-turut 11.16 dan 10.16 ton ha $^{-1}$ (BPS dan Ditjen Hortikultuta, 2015). Namun demikian, produktivitas pada musim hujan jauh di bawah produktivitas Provinsi Jawa Tengah dan produktivitas nasional tahun 2015. 
Uji korelasi pada taraf 5\% menunjukkan tidak terdapat korelasi yang nyata antara pemupukan $\mathrm{P}$ dengan produksi pada musim kemarau $(r=0.090)$ dan produksi pada musim hujan $(r=0.266)$. Hasil tersebut menunjukkan bahwa pemupukan $\mathrm{P}$ yang dilakukan petani sangat bervariasi dari 22 sampai $171 \mathrm{~kg} \mathrm{P}_{2} \mathrm{O}_{5}$ $\mathrm{ha}^{-1}$ tidak secara nyata meningkatkan produksi, walaupun korelasinya masih positif. Pemupukan P pada musim hujan relatif lebih berpengaruh positif terhadap produksi. Tidak terdapat korelasi yang nyata antara pemupukan $\mathrm{K}$ dengan produksi pada musim kemarau $(\mathrm{r}=$ 0.341 ), namun terdapat korelasi yang nyata dengan produksi pada musim hujan $(\mathrm{r}=$ $0.532 *$. Korelasi tersebut menunjukkan bahwa pemupukan K yang dilakukan petani di empat desa di Brebes yang sangat bervariasi dari 22 sampai $213 \mathrm{~kg} \mathrm{~K}_{2} \mathrm{O}$ ha $^{-1}$ hanya nyata meningkatkan produksi bawang pada musim hujan.

Pemupukan memberi tambahan unsur hara yang tidak mampu diberikan oleh tanah untuk tanaman dapat tumbuh dan berproduksi maksimal. Oleh karena itu, apabila hara tanah sudah tinggi, maka tanaman tidak perlu tambahan pupuk, atau apabila diberi tambahan pupuk tidak akan meningkatkan produksi secara nyata. Sesuai data Balitbangtan (2006) status hara $\mathrm{P}$ dan $\mathrm{K}$ tanah sawah yang digunakan untuk pertanaman bawang merah di Brebes sudah tinggi. Oleh karena itu, pemupukan $\mathrm{P}$ sudah tidak nyata lagi meningkatkan produksi.
Sumarni et al. (2012) menunjukkan bahwa peningkatan pemupukan $\mathrm{P}$ dari 60 menjadi $120 \mathrm{~kg} \mathrm{P}_{2} \mathrm{O}_{5} \mathrm{ha}^{-1}$ pada tanah dengan status $\mathrm{P}$ tinggi tidak meningkatkan produksi bawang merah. Pemupukan $\mathrm{K}$ hanya nyata meningkatkan produksi di musim hujan dikarenakan sifat unsur $\mathrm{K}$ yang mobil dan mudah tercuci dari daerah perakaran. Pada tanah-tanah yang telah memiliki residu unsur hara yang tinggi, perlu upaya lain untuk dapat meningkatkan efisiensi penggunaan hara yang telah ada dalam tanah, seperti dengan menambahkan pupuk organik atau pupuk hayati agar unsur hara yang telah terakumulasi di dalam tanah dapat diserap tanaman secara optimal. Kalaupun diperlukan, penambahan pupuk anorganik tidak dalam jumlah yang tinggi. Beberapa penelitian telah menunjukan bahwa pemberian pupuk organik dan/atau pupuk hayati mampu meningkatkan efisiensi penggunaan unsur hara $\mathrm{N}, \mathrm{P}$, dan $\mathrm{K}$ dan mengurangi kebutuhan pupuk anorganik, serta meningkatkan pertumbuhan dan produksi tanaman, termasuk bawang merah (Firmansyah et al., 2016; Suwandi et al., 2015; Purba, 2016; Puspitasari et al., 2017; Lasmini et al., 2017). Rekomendasi pemupukan bawang merah Distan Brebes (2007) diduga sudah tidak relevan lagi dengan kondisi tanah saat ini. Perlu dilakukan penelitian lebih detil terkait pemupukan dan peningkatan efisiensi serapan hara pada pertanaman bawang merah untuk membangun rekomendasi pemupukan yang lebih sesuai, sebagaimana dilakukan untuk tanaman cabai oleh Widyanti dan Susila (2015).

Tabel 4. Produktivitas bawang merah petani di empat desa di Brebes

\begin{tabular}{ccc}
\hline \multirow{2}{*}{ Responden } & \multicolumn{2}{c}{ Produktivitas $\left(\right.$ ton $\left.^{-1}{ }^{-1}\right)$} \\
\cline { 2 - 3 } & Musim Kemarau & Musim Hujan \\
\hline 1 & 11.43 & 5.71 \\
2 & 14.29 & 7.14 \\
3 & 11.43 & 6.85 \\
4 & 11.43 & 5.71 \\
5 & 8.57 & 4.29 \\
6 & 17.50 & 7.00 \\
7 & 11.43 & 8.57 \\
8 & 14.29 & 7.14 \\
9 & 11.43 & 5.71 \\
10 & 9.00 & 6.00 \\
11 & 8.57 & 4.29 \\
12 & 10.00 & 6.00 \\
13 & 8.00 & 6.40 \\
14 & 7.11 & 5.69 \\
\hline Rata-rata & 11.03 & 6.18 \\
\hline
\end{tabular}




\section{Residu $\mathbf{P}$ dan $\mathrm{K}$ pada Tanah Pertanian Intensif di Dua Desa di Brebes}

Hasil analisis $\mathrm{pH} \mathrm{H}_{2} \mathrm{O}$, kadar P-Olsen, $\mathrm{P}-\mathrm{HCl} 25 \%$, dan $\mathrm{K}-\mathrm{HCl} 25 \%$ pada setiap tanah petani responden pada kedalaman $0-20 \mathrm{~cm}$ tanah disajikan pada Tabel 5. Reaksi atau $\mathrm{pH}$ tanah berkisar dari 5.77 sampai 7.45 dengan rata-rata 6.41, dan tergolong dalam kategori agak masam sampai netral. Nilai $\mathrm{pH}$ tanah ini relatif lebih tinggi dibanding $\mathrm{pH}$ tanah lahan kering di Indonesia, dan diduga terutama sebagai hasil dari kondisi dominan anaerob tanah yang sering tergenang (sawah) yang meningkatkan $\mathrm{pH}$ tanah. Kondisi anaerob pada tanah ini ditunjang oleh kondisi tanah yang berteksur liat dan sudah hampir tidak berstruktur bahkan masif.

Kadar P-Olsen yang merupakan ukuran ketersediaan $\mathrm{P}$ pada tanah bereaksi agak masam sampai netral, berkisar dari 61 sampai 252 dengan rata-rata 167 ppm $\mathrm{P}_{2} \mathrm{O}_{5}$, tergolong pada kategori sangat tinggi (batas sangat tinggi ialah $>60 \mathrm{ppm}_{2} \mathrm{O}_{5}$ ). Demikian pula halnya, kadar $\mathrm{P}-\mathrm{HCl} 25 \%$ yang merupakan ukuran $\mathrm{P}$ potensial, berkisar dari 94 sampai 191 dengan rata-rata $140 \mathrm{mg} \mathrm{P}_{2} \mathrm{O}_{5} 100 \mathrm{~g}^{-1}$ tergolong sangat tinggi (batas sangat tinggi ialah $>60 \mathrm{mg} \mathrm{P}_{2} \mathrm{O}_{5}$ $\left.100 \mathrm{~g}^{-1}\right)$. Berbeda dengan P, kadar K-HCl 25\% lebih variatif, berkisar dari 30 sampai 66 dengan rata-rata $55 \mathrm{mg} \mathrm{K}_{2} \mathrm{O} 100 \mathrm{~g}^{-1}$ yang tergolong sedang sampai sangat tinggi (batas sedang, tinggi dan sangat tinggi berturut-turut adalah 21-40, 41-60 dan > $60 \mathrm{ppmK}_{2} \mathrm{O} 100 \mathrm{~g} \mathrm{~g}^{-1}$ ).

Hasil analisis $\mathrm{P}$ dan $\mathrm{K}$ sampel tanah berdasarkan kedalaman disajikan pada Gambar 3 dan 4. Hampir semua lapisan tanah sampai kedalaman $80 \mathrm{~cm}$ memiliki kadar P-Olsen dan $\mathrm{P}-\mathrm{HCl} 25 \%$ sangat tinggi, kecuali profil di Desa Kersana pada lapisan 40-60 dan 60-80 dengan kadar P-Olsen tinggi (Gambar 3). Status kadar $\mathrm{K}-\mathrm{HCl} 25 \%$ berdasarkan kedalaman (Gambar 4) lebih variatif, tergolong dari sedang sampai tinggi. Berdasarkan data tersebut, diduga praktek pengelolaan pertanaman bawang merah dengan membuat parit (dapat sampai kedalaman $80 \mathrm{~cm})$ dan kegiatan malem (menaikkan lumpur parit ke bedengan untuk membumbun dan menguatkan bedengan) menjadi penyebab utama terjadinya akumulasi hara, khususnya unsur P di lapisan bawah.

Tabel 5. Nilai pH, Kadar P-Olsen, P-HCl 25\%, dan K-HCl 25\% tanah (0-20 cm) di empat desa di Brebes

\begin{tabular}{|c|c|c|c|c|}
\hline \multirow[b]{2}{*}{ Sampel } & \multirow[b]{2}{*}{$\mathrm{pH} \mathrm{H} \mathrm{H}_{2} \mathrm{O}$} & \multicolumn{2}{|c|}{ Kadar $\mathrm{P}_{2} \mathrm{O}_{5}$} & \multirow{2}{*}{ 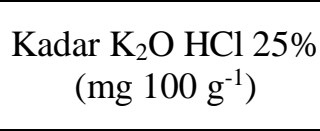 } \\
\hline & & $\begin{array}{l}\text { Olsen } \\
(\mathrm{ppm})\end{array}$ & $\begin{array}{c}\mathrm{HCl} 25 \% \\
\left(\mathrm{mg} 100 \mathrm{~g}^{-1}\right)\end{array}$ & \\
\hline 1 & $5.77 \mathrm{AM}$ & $103 \mathrm{ST}$ & $117 \mathrm{ST}$ & $43 \mathrm{~T}$ \\
\hline 2 & $6.45 \mathrm{AM}$ & $61 \mathrm{ST}$ & $94 \mathrm{ST}$ & $30 \mathrm{~S}$ \\
\hline 3 & $7.05 \mathrm{~N}$ & $134 \mathrm{ST}$ & $151 \mathrm{ST}$ & $58 \mathrm{~T}$ \\
\hline 4 & $6.84 \mathrm{~N}$ & $171 \mathrm{ST}$ & $138 \mathrm{ST}$ & $64 \mathrm{ST}$ \\
\hline 5 & $7.02 \mathrm{~N}$ & $227 \mathrm{ST}$ & $144 \mathrm{ST}$ & $48 \mathrm{~T}$ \\
\hline 6 & $6.24 \mathrm{AM}$ & $219 \mathrm{ST}$ & $144 \mathrm{ST}$ & $60 \mathrm{~T}$ \\
\hline 7 & $6.18 \mathrm{AM}$ & $176 \mathrm{ST}$ & $119 \mathrm{ST}$ & $58 \mathrm{~T}$ \\
\hline 8 & $6.31 \mathrm{AM}$ & $213 \mathrm{ST}$ & $148 \mathrm{ST}$ & $63 \mathrm{ST}$ \\
\hline 9 & $7.02 \mathrm{~N}$ & $235 \mathrm{ST}$ & $131 \mathrm{ST}$ & $66 \mathrm{ST}$ \\
\hline 10 & $6.02 \mathrm{AM}$ & $211 \mathrm{ST}$ & $133 \mathrm{ST}$ & $65 \mathrm{ST}$ \\
\hline 11 & $5.82 \mathrm{AM}$ & $252 \mathrm{ST}$ & $133 \mathrm{ST}$ & $64 \mathrm{ST}$ \\
\hline 12 & $6.41 \mathrm{AM}$ & $121 \mathrm{ST}$ & $171 \mathrm{ST}$ & $50 \mathrm{~T}$ \\
\hline 13 & $6.39 \mathrm{AM}$ & $96 \mathrm{ST}$ & $147 \mathrm{ST}$ & $54 \mathrm{~T}$ \\
\hline 14 & $6.22 \mathrm{AM}$ & $120 \mathrm{ST}$ & $191 \mathrm{ST}$ & $52 \mathrm{~T}$ \\
\hline Rata-rata & $6.41 \mathrm{AM}$ & $167 \mathrm{ST}$ & $140 \mathrm{ST}$ & $55 \mathrm{~T}$ \\
\hline
\end{tabular}

Keterangan: $\mathrm{ST}=$ sangat tinggi; $\mathrm{T}=$ tinggi; $\mathrm{S}=$ sedang; $\mathrm{M}=$ masam; $\mathrm{AM}=$ agak masam; $\mathrm{N}=$ netral. 

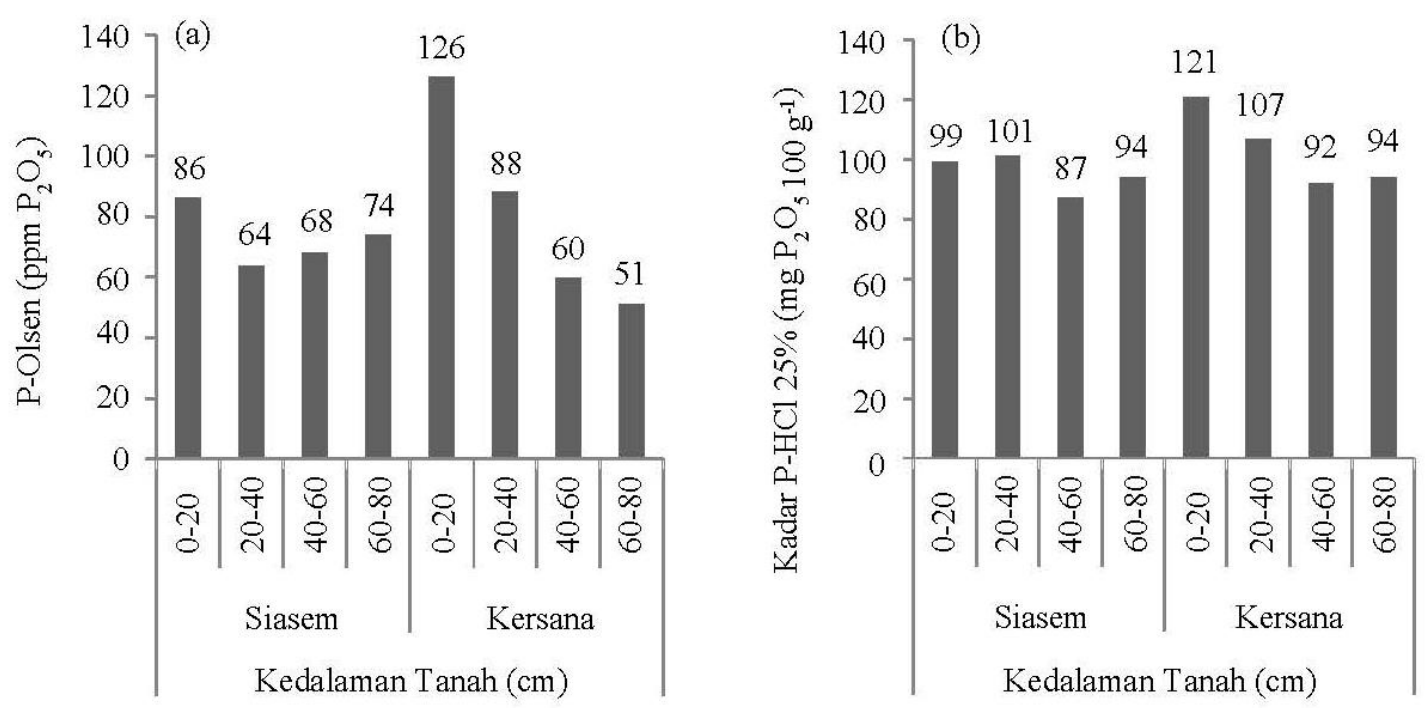

Gambar 3. Kadar P-Olsen (a) dan P-HCl 25\% (b) pada kedalaman 0-20, 20-40, 40-60, dan 60-80 cm tanah pada tanah pertanian intensif di lokasi Desa Siasem dan Kersana, Brebes.

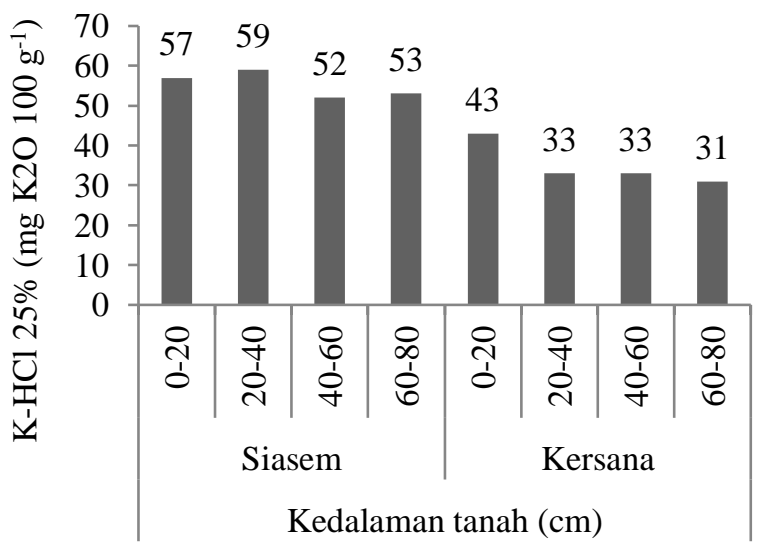

Gambar 4. Kadar K HCl 25\% pada kedalaman 0-20, 20-40, 40-60, dan 60-80 cm tanah pada tanah pertanian intensif di lokasi Desa Siasen dan Kersana, Brebes.

Akumulasi residu unsur hara khususnya $P$ yang tinggi terjadi pada lahan-lahan pertanian di dunia dikenal sebagai legacy $P$ (Ringeval et al., 2014; Rowe et al., 2016; Rodrigues et al., 2016; Chen et al., 2017). Efisiensi pemupukan $\mathrm{P}$ rendah sebagai akibat imobilisasi unsur $\mathrm{P}$ oleh berbagai reaksi dalam tanah, seperti jerapan oleh oksihidroksida $\mathrm{Al} /$ $\mathrm{Fe}$ dan mineral klei, imobilisasi oleh ion $\mathrm{Al} /$ $\mathrm{Fe} / \mathrm{Ca}$, dan reaksi kompleks dengan senyawa organik tanah (Tiecher et al., 2012; Yan et al., 2013; Powers et al., 2016; Rodrigues et al., 2016; Chen et al., 2017; Yan et al., 2017). Bergantung pada sumbernya, sebanyak 60 sampai $85 \% \mathrm{P}$ dari pupuk terakumulasi di dalam tanah sebagai residu P (Sattari et al., 2012; Haygarth et al., 2014; Powers et al., 2016; Chen et al., 2017). Akumulasi residu P umumnya terjadi pada tanah pertanian yang dikelola petani kecil (smallholder farmers) dikarenakan kurangnya informasi dan pembinaan tentang pemupukan yang tepat dan sesuai dengan kebutuhan tanaman. Petani kecil umumnya cenderung memupuk berlebih tanpa mempertimbangkan jumlah hara yang terkandung di pupuk maupun adanya residu hara dalam tanah. Di masa mendatang, pengelolaan hara pertanaman harus mempertimbangkan keberadaan residu hara yang telah ada pada tanah. 


\section{KESIMPULAN}

Penanaman bawang merah pada pertanian intensif di empat desa di Brebes, umumnya dilakukan tiga sampai empat kali berturut-turut dan sekali padi dengan IP 400$500 \%$ dalam setahun. Pemupukan dilakukan tiga sampai lima tahap dalam sekali musim tanam. Jumlah responden menggunakan pupuk $\mathrm{P}$ di atas dosis anjuran $66 \%$ dan di bawah anjuran $44 \%$. Pengguna pupuk K di atas dosis anjuran $43 \%$, sesuai dosis anjuran, dan di bawah dosis anjuran 57\%. Produktivitas bawang merah pada musim kemarau dan musim hujan berturut-turut 11.03 dan 6.10 ton $\mathrm{ha}^{-1}$. Pemupukan $\mathrm{P}$ tidak berkorelasi nyata dengan produksi, sementara pemupukan $\mathrm{K}$ hanya berkorelasi nyata dengan produksi pada musim hujan. Status P tanah sangat tinggi dan status $\mathrm{K}$ berkisar antara sedang sampai sangat tinggi. Residu $\mathrm{P}$ dan $\mathrm{K}$ yang tinggi ditemukan sampai kedalaman $0.8 \mathrm{~m}$.

\section{UCAPAN TERIMAKASIH}

Terimakasih disampaikan kepada Pusat Kajian Hortikultura (PKHT) yang telah membantu sebagian dana penelitian. Terima kasih juga ditujukan kepada Dinas Pertanian dan Ketahanan Pangan Kabupaten Brebes yang sudah memfasilitasi pelaksanaan survei dan pengambilan sampel dalam penelitian ini.

\section{DAFTAR PUSTAKA}

[Balitbangtan] Badan Penelitian dan Pengembangan Pertanian. 2006. Pemupukan fosfat dan kalium tanah sawah, Kabupaten Brebes. Departemen Pertanian.

[BPS dan Ditjen Hortikultura] Badan Pusat Statistik dan Direktorat Jendral Hortikultura. 2015. Produktivitas Bawang Merah Menurut Provinsi. Badan Pusat Statistik dan Direktorat Jendral Hortikultura.

Chen, D., M. Hu, Y. Guo, J. Wang, H. Huang, R.A. Dahlgren. 2017. Long-term (1980-2010) changes in cropland phosphorus budgets, use efficiency and legacy pools across townships in the Yongan Watershed, Eastern China. Agriculture, Ecosystem \& Environment. 236: 166-176.

[Distan Brebes] Dinas Pertanian Kehutanan dan Konservasi Tanah Kabupaten Brebes. 2007. Profil Bawang Merah. Dinas Pertanian Kehutanan dan Konservasi Tanah Kabupaten Brebes.

Eviati, Sulaeman. 2012. Petunjuk Teknis Analisis Kimia Tanah, Tanaman, Air, dan Pupuk. Balai Penelitian dan Pengembangan Pertanian, Departemen Pertanian.

Firmansyah, I., L. Lukman, N. Khaririyatun, M.P. Yufdy. 2016. Pertumbuhan dan hasil bawang merah dengan aplikasi pupuk organik dan pupuk hayati pada tanah alluvial. J. Hort. 25(2): 133-141.

Hartono, A., S. Anwar, A. Satwoko, K. Koyama, T. Omoto, A. Nakao, J. Yanai. 2015. Phosphorus fractions of paddy soil in Java, Indonesia. J. ISSAAS. 21(2): 20-30.

Haygarth, P.M., H.P. Jarvie, S.M. Powers, A.N. Sharpley, J.J. Elser, J.B. Shen, H.M. Peterson, N.I. Chan, N.J.K. Howden, T. Burt, F. Worrall, F.S. Zhang, X.J. Liu. 2014. Sustainable phosphorus management and the need for a long-term perspective: the legacy hypothesis. Environ. Sci. Technol. 48: 8417-8419.

Lasmini, S.A., I. Wahyudi, B. Nasir, Rosmini. 2017. Pertumbuhan dan hasil bawang merah Lembah Palu pada berbagai dosis pupuk organik cair biokultur urin sapi. J. Agroland. 24(3): 199-207.

Mubyarto. 1991. Pengantar Ekonomi Pertanian. Penelitian, Pendidikan dan Penerangan Ekonomi dan Sosial (LP3ES). Jakarta.

Powers, S.M., T.W. Bruulsema, T.P. Burt, N.I. Chan, P.M. Haygarth, N.J.K. Howden, H.P. Jarvie, Y. Lyu, H.D. Peterson, A.N. Sharpley, J.B. She, F. Worrall, F.S. Zhang. 2016. Long-term accumulation 
and transport of anthropogenic phosphorus in three river basins. Nature Geosci. 29: 353-356.

Purba, R. 2016. Kajian penggunaan pupuk organik pada sistem usahatani bawang merah di Serang Banten. Planta Tropika Journal of Agro Science. 4(1): 1-6. DOI 10.18196/pt.2016.049.1-6.

Puspitasari, R.A., N. Azizah, M. Santosa. 2017. Pengaruh aplikasi biourin sapi, EM4 dan macam pupuk pada pertumbuhan dan hasil bawang merah (Allium ascalonicum L.) di musim hujan. J. Produksi Tanaman. 5(2): 240-248.

Ringeval, B., B. Nowak, T. Nesme, M. Delmas, S. Pellerin. 2014. Contribution of anthropogenic phosphorus to agricultural soil fertility and food production. Glob. Biogeochem. Cycles. 28: 743-756.

Rodrigues, M., P.S. Pavinto, P.J.A. Withers, A.P.B. Teles, W.F.B. Herrera. 2016. Legacy phosphorus and no tillage agriculture in tropical oxisols of the Brazilian savanna. Sci. Total Environ. 542: 1050-1061.

Rowe, H., P.J.A. Withers, P. Baas, N.I. Chan, D. Doody, J. Holiman, B.Jacobs, H. Li, G.K. MacDonald, R. McDowell, A.N. Sharpley, J. Shen, W. Taheri, M. Wallenstein, M.N. Weintraub. 2016. Integrating legacy soil phosphorus into sustainable nutrient management strategies for future food, bioenergy and water security. Nutr. Cycl. Agroecosyst. 104(3): 393-412.
Sattari, S.Z., A.F. Bouwman, K.E. Giller, M.K. van Ittersum. 2012. Residual soil phosphorus as the missing piece in the global phosphorus crisis puzzle. Proc. Natl. Acad. Sci. 109: 6348-6353.

Sumarni, N., R. Rosliani, R.S. Basuki, Y. Hilman. 2012. Respon tanaman bawang merah terhadap pemupukan fosfat pada beberapa tingkat kesuburan lahan (status P-tanah). J. Hort. 22(2): 129-137.

Suwandi, G.A. Sopha, L. Lukman, M.P. Yufdy. 2015. Efektivitas pengelolaan pupuk organik, NPK, dan pupuk hayati terhadap pertumbuhan dan hasil bawang merah. J. Hort. 25(3): 208-221

Tiecher, T., D.S. Rheinheimer, J. Kaminski, A. Calegari. 2012. Forms of inorganic phosphorus in soil under different long term soil tillage systems and winter crops. Braz. J. Soil Sci. 36: 271-281.

Widyanti, A.S., A.D. Susila. 2015. Rekomendasi pemupukan kalium pada budi daya cabai merah besar (Capscicum annuum L) di Inceptisols Dramaga. J. Hort. Indonesia. 6(2): 65-74.

Yan, X., D. Wang, H. Zhang, G. Zhang, Z. Wei. 2013. Organic amendments affect phosphorus sorption characteristics in a paddy soil. Agric. Ecosyst. Environ. 175: 47-53.

Yan, X., Z. Wei, Q. Hong, Z. Lu, J. Wu. 2017. Phosphorus fractions and sorption characteristics in a subtropical paddy soil as influenced by fertilizer sources. Geoderma. 295: 80-85. 